\title{
Flavonoids of Lotus tenuis (Waldst. \& Kit.) as Markers of Populations Growing in Soils of Different Saline and Hydrologic Conditions
}

\author{
Graciela Ferraro, ${ }^{a}$ Rosana Filip, ${ }^{*, a}$ María A. del Pero, ${ }^{a}$ Norma Basualdo, ${ }^{a}$ \\ Rodolfo Mendoza $a^{b}$ and Ileana García ${ }^{b}$
}

aPlant Physiology, School of Pharmacy and Biochemistry, IQUIMEFA (UBA-CONICET), University of Buenos Aires, Junín 956, 1113 Buenos Aires, Argentina

${ }^{b}$ Bernardino Rivadavia, Argentine Museum of Natural Sciences (CONICET), Av. Ángel Gallardo, 470, 1405 Buenos Aires, Argentina

\begin{abstract}
Lotus tenuis Waldst. et Kit. (=Lotus glaber Mill.) é uma planta leguminosa muito difundida que cresce naturalmente em pastagens da Flooding Pampas, na Argentina. Uma das hipóteses para explicar a disseminação de L. tenuis nessa área, é a diferenciação de ecotipos. O objetivo deste trabalho foi investigar os compostos flavonoides presentes em populações de L. tenuis que crescem em uma grande variedade de solos. Amostras de cinco populações que crescem em solos com diferentes características foram coletados, cultivados em estufas e comparados de acordo com seu perfil de flavonoides. Glicosídeos dos seguintes flavonoides foram detectados: quercetina, 7-metóxi-quercetina éter, kaempferol, 7-metóxi-kaempferol éter e isorhamnetina. Somente as mostras de solos salino-sódicos mostraram agliconas metiladas: 7-metóxi-kaempferol éter e 7-metóxi-quercetina éter. Os últimos compostos poderiam, portanto, ser considerados como a expressão de uma adaptação bioquímica e sugerem uma diferenciação em ecotipo.
\end{abstract}

Lotus tenuis Waldst. et Kit. (=Lotus glaber Mill.) is a widely spread leguminous plant which grows naturally in low grasslands of the Flooding Pampas of Argentina. One of the hypothesis to explain the succesful spread of $L$. tenuis in this area, is the ecotypes differentiation. The aim of this work was to investigate the flavonoid compounds present in L. tenuis plant populations which grow in a variety of soils. Individuals from five populations growing in soils having different characterisctics were collected, cultivated in a glasshouse and compared according to their flavonoid profile. Glycosides of the following flavonoids were detected: quercetin, quercetin 7-methyl ether, kaempferol, kaempferol 7-methyl ether and isorhamnetin. Only those samples from a saline-sodic lowland, showed methylated aglycones: kaempferol 7-methyl ether and quercetin 7-methyl ether. The latter compounds could therefore be considered the expression of a biochemical adaptation and suggest an ecotype differentiation.

Keywords: Lotus tenuis, flavonoids, ecotype, environment adaptation, soil gradient

\section{Introduction}

Species of the genus Lotus are increasingly used in pastures over the world because of their plasticity and productivity in a wide range of soils. ${ }^{1}$ Lotus tenuis Waldst. \& Kit. (Lotus glaber Mill.) is a widely spread leguminous plant which grows naturally in the low grasslands of a region known as the Flooding Pampas of Argentina. ${ }^{2}$ It is highly esteemed by farmers because it is a source of nutritive forage for beef and dairy cattle in a normally

*e-mail: rfilip@ffyb.uba.ar nutrient deficient soils which are poor for agricultural purposes. The productivity of the grasslands in the Flooding Pampas is strongly affected by stress factors such as salinity, sodicity and an excess or deficit of water in soil, depending upon the climate and season. Thus, the presence of L. tenuis in those plant communities is crucial for the quality of the native grassland for cattle, especially in winter. ${ }^{3,4}$

The spreading of L. tenuis in the heterogeneous environment of the Pampas's grassland could be explained by a high phenotypic plasticity and/or genetic variations between the individuals. Previous studies have suggested the existence of $L$. tenuis ecotypes which can be distinguished 
by morphological attributes ${ }^{5}$ but also by their different capacity to absorb phosphorus from soils defficient in this. ${ }^{6}$ While $L$. tenuis is adapted to low fertility conditions, it is highly dependent on arbuscular mycorrhiza symbiosis to grow at low phosphorus availability in the soil. ${ }^{7}$ This symbiotic association could be one of the explanations for the successful adaptation of Lotus to the variety of nutrientdeficient soils encountered in the Flooding Pampas.

The richness and diversity of flavonoid compounds in Lotus species tissues has been demonstrated and some authors have used flavonoids as speciation markers within Lotus species. ${ }^{8}$ Flavonoids have been successfully used to differentiate seeds of $L$. tenuis from $L$. corniculatus, ${ }^{9}$ suggesting that these compounds might be important markers for distinguishing populations or ecotypes. Preliminary studies have demonstrated the presence of different flavonoid compounds in the leaves of $L$. tenuis collected along a saline-sodic gradient. ${ }^{10}$ Flavonoid extracts from roots and shoots of white clover revealed that the compositions of the flavonoid mixtures varied with soil growing conditions and quercetin, acacetin and rhamnetin accumulated in roots of arbuscular mycorrhizas inoculated plants, whereas they were not detected in noninoculated plants. ${ }^{11}$ The synthesis of flavonoids appears to increase the presence of arbuscular mycorrhiza even before colonization. ${ }^{12}$

The aim of this work was to investigate the distribution of flavonoids in L. tenuis plant communities in populations of the Flooding Pampas in an attempt to provide a means of differentiation of the ecotypes which grow in a variety of soils.

\section{Experimental}

\section{Lotus tenuis populations}

The Flooding Pampas is a grassland with a surface of $90,000 \mathrm{~km}^{2}$, which extends along the Atlantic coast from the NW to the SE of the Buenos Aires Province in Argentina ( $34^{\circ} 50^{\prime}$ to $37^{\circ} 40^{\prime} \mathrm{S}$; $56^{\circ} 40^{\prime}$ ' to $61^{\circ} 00^{\prime} \mathrm{W}$ ).

Out of a total of 18 grassland sites of the Flooding Pampas in Buenos Aires Province, 5 were selected based on their different soil characteristics such as: $\mathrm{pH}$, phosphorus (P) status, salinity, hydrologic condition during the year and the presence of $L$. tenuis in the plant community. There is a high variability in soil characteristics among the soil sites sampled (Table 1). Site 1 (Verónica) is an abandoned disturbed pasture with acidic soil, high clay content and dominated by L. tenuis, Phyla canescens (H.B.K.) Greene, Eryngium ebracteum Lam. and Piptochaetium bicolor (Vahl) Desv.
Sites 2 (Monte), 3 (San Vicente), 4 (Samborombón) and 5 (Chascomús) are all frequently grazed natural grasslands. Site 2 is a sandy lowland of neutral soil $\mathrm{pH}$ dominated by L. tenuis, Ambrosia tenuifolia Spreng., Cyperus laetus C. Presl. and Juncus microcephalus H.B.K. Site 3 is a typical saline-sodic lowland, frequently flooded and dominated by L. tenuis, Distichlis spicata (L) Greene., Eleocharis viridans Kükenth and Cynodon dactylon (L) Pers. In Site 4, L. tenuis, Stenotaphrum secundatum (Walt.) O.K., Lolium multiflorum Lam., Stipa paposa Nees. and Paspalum dilatatum Poir are predominant, whereas in Site 5, L. tenuis, Bothriochloa laguroides (DC) Pilg., Paspalum dilatatum Poir, and Carex sp., are the prevailing species. These latter two sites (4 and 5) are at an intermediate altitude topographic position between site 1 and 2 or 3 . As voucher specimens, 5 individuals (shoots and roots) of L. tenuis with undisturbed surrounding soil were collected at random in each of the 5 field sites. These individuals were then transplanted into $5 \mathrm{~L}$ pots containing their native soils. Plants were grown in a glasshouse at $27{ }^{\circ} \mathrm{C} \pm 5{ }^{\circ} \mathrm{C}$ during 10 months until flowering with a water content in the soil near to the field capacity. Soil characteristics were determined as described by Jackson. ${ }^{13}$ Flavonoids from leaves and flowers proceeding from plants collected in the 5 locations were analysed. These locations were between 60 and $140 \mathrm{~km}$ apart and had different edaphic conditions, principally the $\mathrm{pH}$, salinity, organic matter, nitrogen and phosphorus content and texture of the soil (Table 1). Additionally, the roots of L. tenuis plants collected from all the sites were analysed for arbuscular mycorrhiza colonization. ${ }^{14}$

\section{Flavonoids investigation}

$2.0 \mathrm{~g}$ of plant material was heated under reflux with $20 \mathrm{~mL}$ of $80 \%$ methanol overnight. The extract was filtered and the procedure was repeted twice. The extracts were combined and taken to dryness in a rotatory evaporator and redissolved in $5.0 \mathrm{~mL}$ of methanol.

$2.0 \mathrm{~mL}$ of the methanolic extract were analysed by bidimensional chromatography on cellulose precoated plates with two mobile phases: BAW ( $n$-butanol:acetic acid:water, 4:1:5, top layer used) (first dimension) followed by $2 \%$ acetic acid (second dimension). The flavonoid glycosides were detected under UV light at $254 \mathrm{~nm}$ and $366 \mathrm{~nm}$ before and after fuming in $\mathrm{NH}_{3}$, following the maps indicated by Mabry et al. ${ }^{15}$

For the hydrolysis of the flavonoids glycosides, $2.0 \mathrm{~mL}$ $\mathrm{HCl}\left(2 \mathrm{~mol} \mathrm{~L}^{-1}\right)$ were added to $2.0 \mathrm{~mL}$ of the methanolic extract and heating during $1 \mathrm{~h}$. The solution was cooled and extracted with 3 volumes of ethyl acetate, the organic 
Table 1. Chemical and physical characteristics of the five selected grassland sites of the Flooding Pampas in Buenos Aires province

\begin{tabular}{lccccc}
\hline Soil property & \multicolumn{5}{c}{ Location and soil site } \\
\cline { 2 - 6 } & Verónica (Site 1) & Monte (Site 2) & San Vicente (Site 3) & Samborombón (Site 4) & Chascomús (Site 5) \\
\hline $\mathrm{pH}(1: 2.5)$ & $5.63 \pm 013$ & $7.38 \pm 1.10$ & $9.03 \pm 0.43$ & $7.64 \pm 0.45$ & $5.60 \pm 0.14$ \\
$\mathrm{C}\left(\mathrm{g} \mathrm{kg}^{-1}\right)^{*}$ & 55.3 & 26.6 & 16.0 & 69.7 & 28.9 \\
$\mathrm{~N}\left(\mathrm{~g} \mathrm{~kg}^{-1}\right)^{*}$ & 4.53 & 2.34 & 1.84 & 5.22 & 2.26 \\
$\mathrm{P} \mathrm{Bray} \mathrm{I}\left(\mathrm{mg} \mathrm{kg}^{-1}\right)$ & $1.38 \pm 0.31$ & $6.23 \pm 3.31$ & $8.60 \pm 2.37$ & $6.88 \pm 3.22$ & $6.10 \pm 2.65$ \\
$\mathrm{EC}(\mathrm{dS} / \mathrm{m})$ & $0.51 \pm 0.28$ & $1.93 \pm 1.60$ & $5.03 \pm 0.37$ & $1.52 \pm 0.61$ & $1.15 \pm 0.52$ \\
$\mathrm{ESP} /(\%)$ & 7.30 & 24.42 & 81.22 & 27.84 & 25.57 \\
$\mathrm{Clay} /(\%)^{*}$ & 38.7 & 3.7 & 30.5 & 26.7 & 15.7 \\
Loam/(\%)* & 52.4 & 9.6 & 51.4 & 60.2 & 51.1 \\
Sand/(\%)* & 8.9 & 86.7 & 18.1 & 13.1 & 33.2 \\
\hline
\end{tabular}

* Mean of two measures (less than $5 \%$ of variation) from one composite sample.

phases were pooled, evaporated to dryness and redissolved in $1.0 \mathrm{~mL}$ of methanol for aglycones investigation.

The aqueous phase was concentrated in a rotatory evaporator and reserved for sugars analysis.

For the aglycones investigation, $5.0 \mu \mathrm{L}$ of the methanol extract were chromatografied on cellulose precoated thin layer plates using as mobile phase: ( $\mathrm{HCl}: \mathrm{HOAc}: \mathrm{H}_{2} \mathrm{O}$, 3:30:10) and 40\% aqueous HOAc. The flavonoids were detected using $\mathrm{UV}$ at $365 \mathrm{~nm}$ and spray reagents according to Wagner and Bladt. ${ }^{16}$ The fraction was also subjected to one dimensional semipreparative TLC using cellulose plates and BAW (n-butanol:acetic acid:water, 4:1:5, top layer) as solvent. The standard flavonoids: quercetin, isorhamnetin and kaempferol were used as reference compounds. Subsecuently all the flavonoids were isolated and identified by a combination of $(i)$ colour characteristics on TLC plates under UV light before and after fuming in $\mathrm{NH}_{3}$ and spray reagents ${ }^{16}$ (ii) (Rf) values on TLC plates, (iii) co-chromatography with standard compounds and (iv) UV spectra and shifts reagent according to literature. ${ }^{15,17}$ For kaempferol 7-methyl ether and quercetin 7-methyl ether, their identities were confirmed by MS spectra; kaempferol 7-methyl ether (Ms: 300, 100\%), quercetin 7-methyl ether (Ms: 316, 100\%). ${ }^{17}$ The relative content of each constitutive flavonoid aglycone was estimated semi-quantitatively.

\section{Analysis of sugars by GC-MS}

The aqueous remaining phase was subjected to GC-MS analysis for the sugars study following the method described by Horbowics and Obendorf. ${ }^{18}$ Briefly, samples were dried under $\mathrm{N}_{2}$ gas and stored overnight above $\mathrm{P}_{2} \mathrm{O}_{5}$ to remove traces of water. Dried residues were derivatised with $100 \mu \mathrm{L}$ of 1-(trimethylsilyl) imidazole (TMSI): pyridine $(1: 1 \mathrm{v} / \mathrm{v})$ and analysed on a GC-MS Clarus 500 (Perkin Elmer) and two capillary columns $(\mathrm{J} \& W)$ : (i) polyethylene glycol (aprox. M.W. 20,000) and (ii) DB-5, both of $60 \mathrm{~m} \times 0.25 \mathrm{~mm}, 25 \mu \mathrm{m}$ of solid phase.

\section{Multivariate analyses}

The canonical correspondence analysis (CCA) ordination technique by CANOCO program ${ }^{19}$ was used. The CANOCO algorithm identifies the best linear combinations of soil properties that influence the synthesis of a given flavonoid.

The concentration of five flavonoids in both leaves and flowers tissues (10 observations) were analysed in L. tenuis plants collected from the 5 sites and included in the main matrix. They were: kaempferol (KA), quercetin (QU), isorhamnetin (IS), kaempferol-7-methyl ether (K7M), and quercetin-7- methyl ether (Q7M). The second matrix was constituted by 5 soil properties from the 5 sites using a common value for leaves and flowers from the same site (10 observations): $\mathrm{pH}$, total carbon (C), total nitrogen $(\mathrm{N})$, exchangeable sodium percentage (ESP) and electrical conductivity (EC). The analysis allows identifying the best linear combinations of the environmental variables that influence the flavonoid profile in plant tissue. To assess the significance in the CCA axes, the Monte Carlo simulation was used to test the hypothesis that there was no correlation between the main (flavonoids) and secondary (soil properties) matrixes. The $\mathrm{P}$ values were based on the proportion of 1000 Monte Carlo simulations with an Eigen value greater than the Eigen value observed.

\section{Results and Discussion}

\section{Flavonoids composition}

The $L$. tenuis populations analysed in this work proved to have flavonol derivatives exclusively (Figure 1). The 
Table 2. Distribution pattern of flavonoids at the five selected populations in different organs of L. tenuis plants

\begin{tabular}{|c|c|c|c|c|c|c|}
\hline \multirow[t]{2}{*}{ Location and site populations } & \multirow[t]{2}{*}{ Plant organ } & \multicolumn{5}{|c|}{ Flavonoid Aglycones } \\
\hline & & 1 & 2 & 3 & 4 & 5 \\
\hline \multirow[t]{2}{*}{ Verónica (Site 1) } & Leaf & +++ & + & - & - & - \\
\hline & Flower & +++ & +++ & - & - & - \\
\hline \multirow[t]{2}{*}{ Monte (Site 2) } & Leaf & ++ & ++ & - & - & - \\
\hline & Flower & ++ & ++ & ++ & - & - \\
\hline \multirow[t]{2}{*}{ San Vicente (Site 3) } & Leaf & +++ & +++ & ++ & +++ & +++ \\
\hline & Flower & - & +++ & ++ & +++ & - \\
\hline \multirow[t]{2}{*}{ Samborombón (Site 4) } & Leaf & ++ & + & - & - & - \\
\hline & Flower & +++ & ++ & - & - & - \\
\hline \multirow[t]{2}{*}{ Chascomús (Site 5) } & Leaf & ++ & +++ & - & - & - \\
\hline & Flower & ++ & +++ & - & - & - \\
\hline
\end{tabular}

The aglycones units were investigated after hydrolysis of glycosides 1: kaempferol; 2: quercetin; 3: isorhamnetin; 4: kaempferol 7-methyl ether; 5: quercetin 7- methyl ether. Approximate Aglycone amount: +++, 1.0-2.0 $\mu \mathrm{g} \mathrm{g}^{-1} ;++, 0.5-1.0 \mu \mathrm{g} \mathrm{g}^{-1} ;+, 0.1-0.5 \mu \mathrm{g} \mathrm{g}^{-1} ;-$, less than $0.1 \mu \mathrm{g} \mathrm{g}{ }^{-1}$. The values are the average of four to ten determinations and are refered to dry plant material.<smiles>[R]c1ccc(-c2oc3cc(O)cc(O)c3c(=O)c2[R])cc1[Y]</smiles>

$$
\begin{aligned}
& \text { 1. Kaempferol }\left(R^{1}=R^{2}=O H ; R^{3}=H\right) \\
& \text { 2. Quercetin }\left(R^{1}=R^{2}=R^{3}=O H\right) \\
& \text { 3. Isorhamnetin }\left(R^{1}=R^{2}=O H ; R^{3}=O-C H_{3}\right)
\end{aligned}
$$

Figure 1. Structural representations of flavanols identified in this study.

identified aglycones were: kaempferol, isorhamnetin (quercetin 4'-methyl ether), quercetin, quercetin 7-methyl ether and kaempferol 7- methyl ether (Table 2). A large variety of 3-0- mono, di, tri or tetraglycosides were observed (data not shown). Although the glycosidic sequence was not determined, the number and identity of the sugars were determined by GC-MS as: glucose, galactose, rhamnose, xylose and glucuronic acid. It was found that the differences in the type of sugars units obtained after hydrolysis of their glycosides, cannot be used for diagnostic purposes (Table 3).

The aglycones profile of the $L$. tenuis populations are shown in Table 2. Site 1 population was distinguished by the simple profile of leaf extracts, in which the main glycosides were kaempferol derivatives while quercetin glycosides were present at relatively low concentrations (0.1-0.5 $\left.\mu \mathrm{g} \mathrm{g}^{-1}\right)$. Conversely, the flowers showed equal amounts of quercetin and kaempferol glycosides. The presence of glucuronic acid among the detected sugars is noteworthy since it was only found in samples from this population (Table 3 ).
Table 3. Distribution of sugars after hydrolysis of glycosides from the five selected populations in different organs of $L$. tenuis plants

\begin{tabular}{lcc}
\hline Location and site populations & Plant organ & Sugars \\
\hline Verónica (Site 1) & Leaf & G, Ga, R, X, GA \\
& Flower & G, R, GA \\
Monte (Site 2) & Leaf & G, Ga, R, X \\
& Flower & G, R, X, Ga \\
San Vicente (Site 3) & Leaf & G, Ga, R \\
& Flower & G, Ga, R, X \\
Samborombón (Site 4) & Leaf & G, Ga, R \\
& Flower & G, Ga, R \\
Chascomús (Site 5) & Leaf & G, Ga, R \\
& Flower & G, Ga, R \\
\hline
\end{tabular}

G: Glucose; Ga: Galactose; R: Rhamnose; X: Xylose; GA: Glucuronic acid.

Samples from site 2 showed similar content of kaempferol and quercetin glycosides in leaf and flower extracts. Flowers were also found to contain isorhamnetin glycosides.

The simplest leaf extract profile corresponded to samples of the leaf from site 4 , in which kaempferol glycosides were the most abundant compounds $\left(0.5-1.0 \mu \mathrm{g} \mathrm{g}^{-1}\right)$. The flower extracts contained more glycosides than the leaf extract. It is important to note that kaempferol is the major aglycone in both leaf and flower extracts.

Plant material from site 5 was the only one that contained glycosides of kaempferol and quercetin with a clear prevalence of quercetin as aglycone in both, leaf and flower extracts.

Samples from site 3 population showed a different quali and quantitative flavonoid profile from all the other samples. 
The leaf extracts were the richest in flavonoids, showing the major content of kaempferol and quercetin. This sample also contained glycosides from the methylated aglycones: isorhamnetin (quercetin 4'-methyl ether), kaempferol 7-methyl ether and quercetin 7-methyl ether in the highest amount found in all the samples analyzed. Interestingly, the flower extract profiles showed only quercetin and glycosides from the methylated aglycone isorhamnetin and kaempferol 7-methyl ether, but not kaempferol.

Additionally, the roots of the L. tenuis plants collected from the sites were all heavily colonized by arbuscular mycorrhizas, being colonized a $90-97 \%$ of root length.

\section{Multivariate analyses}

The Canonical Correspondence Analysis (CCA) ordination technique by CANOCO program ${ }^{19}$ was used to establish how the flavonoids aglycones (kaempferol (KA), quercetin (QU), isorhamnetin (IS), kaempferol 7-methyl ether (K7M), and quercetin 7-methyl ether (Q7M)) content in tissues of $L$. tenuis plants collected from different sites, are related to environmental factors. The CANOCO algorithm identifies the best linear combinations of soil properties that influence flavonoids content.

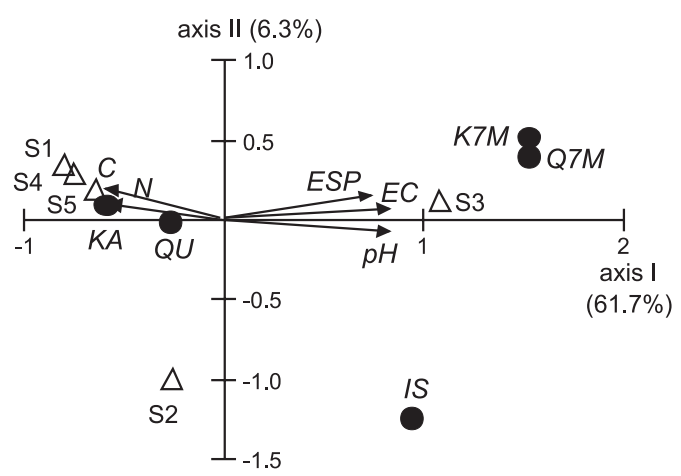

Figure 2. Ordination diagram from the Canonical Correspondence Analysis of $L$. tenuis populations based on flavonoids variables (main matrix) and soil properties (secondary matrix). Sites were identified by open triangles and $\mathrm{S}$ followed by the site number 1-5. Biplot of soil properties correspond to $\mathrm{C}$, carbon; $\mathrm{N}$, nitrogen; $\mathrm{EC}$, electrical conductivity; ESP, exchangeable sodium percentage and soil $\mathrm{pH}$. Flavonoids were identified by closed circle symbols as: kaempferol (KA), quercetin (QU), isorhamnetin (IS), kaempferol-7-methyl ether (K7M), and quercetin-7- methyl ether (Q7M).

Figure 2 shows the observations on the two first ordination axes of the CCA study. The two first axes, indicators of the amount of flavonoids variation, explained the $68.0 \%$ of the total variance (axis I: $61.7 \%$ and axis II: $6.3 \%$ ). The Pearson's correlation coefficient between the scores of the first two axes derived from the flavonoids data and the sample scores that are linear combined with environmental variables were 0.98 and 0.68 respectively, being these values statistically significant. In addition, the Monte Carlo test indicated that the overall effect of the soil properties included in the second matrix and the first canonical axis was significantly correlated at a probability $\mathrm{P}<0.01$. However, axis II did not correlate $(\mathrm{P}<0.88)$. These results indicated that axis I is the most important one to describe the effect of the environment on flavonoids content in plant tissues.

In the first matrix, axis I was positively correlated with $\mathrm{K} 7 \mathrm{M}(\mathrm{P}<0.001), \mathrm{Q} 7 \mathrm{M}(\mathrm{P}<0.05)$ and IS $(\mathrm{P}<0.01)$. Axis II was positively correlated with IS $(\mathrm{P}<0.01)$. Figure 2 also shows that the different flavonoids were segregated to different quadrants. The two methylated flavonoids (kaempferol 7-methyl ether and quercetin 7-methyl ether) were displaced together to the upper right quadrant (K7M and Q7M); IS to the lower right quadrant and the other two flavonoids (KA and QU) were displaced to the left quadrants.

The ordination placed the observations separately by the location. Sites 1, 2, 4 and 5 were segregated to the negative scale of axis I; and site 3 to the positive scale of axis I (Figure 2). The biplots show the ordination of the soil variables of the second matrix ( $\mathrm{pH}, \mathrm{EC}, \mathrm{ESP}, \mathrm{C}$ and $\mathrm{N})$ that were significantly correlated with the axes. The length of the vector describes the relative significance of the correlation of that variable with the axes and the angles between the vectors reflect the inter-correlation between the variables. The angle between a vector and each axis is a representation of the degree of correlation with the corresponding axis. Thus, on the positive scale of axis I, $\mathrm{pH}(\mathrm{P}<0.01)$, EC $(\mathrm{P}>0.001)$ and $\mathrm{ESP}(\mathrm{P}<0.001)$ were positively correlated with this axis but $\mathrm{C}(\mathrm{P}<0.05)$ and $\mathrm{N}$ $(\mathrm{P}<0.05)$ were both negatively correlated.

Different associations emerged in separate parts of the diagram of Figure 2. Highest values of $\mathrm{pH}, \mathrm{CE}$ and ESP in soil occurs to the positive scale of the axis I, associated with the presence of K7M and Q7M flavonoids in leaves and/ or flowers of L. tenuis plants. In addition, the observations from site 3 were also displaced to right side of axis 1 associated with high values of soil $\mathrm{pH}, \mathrm{CE}$ and ESP. The arrows of the $\mathrm{C}$ and $\mathrm{N}$ status in soil are pointing to site 1,4 and 5 closely associated with the presence of KA and QU in L. tenuis tissues.

The flavonoid glycosides composition of the samples was determined using a combination of chromatographic techniques and spectroscopic methods such as TLC, UV and MS spectra. Our survey and identification of flavonoids was conducted using UV spectra and shifts reagents of acid-hydrolyzed ethyl acetate extracts to determine specific flavonoid classes. ${ }^{15,17}$ The sugars identity was determined by GC-MS of the aqueous hydrolyzed extracts. 
According to the results obtained in this work, it is possible to establish differences between the L. tenuis populations based on the structures of the flavonoid aglycones and their corresponding glycosides. Some authors have used flavonoids as speciation markers within the Lotus species ${ }^{8}$ and to differentiate seeds of $L$. tenuis from $L$. corniculatus, ${ }^{9}$ suggesting that these compounds might be important markers to distinguish populations or ecotypes.

A high variability in soil characteristics among the soil sites sampled was found (Table 1). Site 3 is a typical saline-sodic lowland having EC and ESP values higher than $4 \mathrm{dS} / \mathrm{m}$ and $15 \%$ respectively. ${ }^{20}$

Previous studies have suggested the existence of L. tenuis ecotypes which can be differentiated from one another by some morphologic attributes ${ }^{5}$ but also by a different capacity to absorb phosphorus from P-deficient soils. ${ }^{6}$ Furthermore, Kade et al. ${ }^{21}$ have reported that the L. tenuis population growing in site 3 (saline-sodic) exhibited differences in the efficiency of $\mathrm{P}$ utilization with the population growing in site 1 (non saline, non sodic). In addition, $L$. tenuis from populations of site 3 showed longer shoots, internodes and leaflets when compared to the ones belonging to the other five populations (sites 1,2 and 4 were included) when growing in both the original and a common soil. ${ }^{22}$ The authors concluded that these characteristics were due to the existence of a genetic control that suggested the presence of ecotypes adapted to specific soil conditions.

The principal differences between sites are referred to the glycoside content and the type of chromatographic profile of the leaf and flower extracts. The population collected in site 1 is notable for the presence of glycosides with glucuronic acid residues, which is very rare and was not observed in other populations. This characteristic shows a remarkable difference with the population from site 3 coinciding with the differences in the observed morphological characteristics and their phosphorus absorbing capacity reported in previous works. ${ }^{21,22}$

According to the results obtained in this work, it is possible to establish differences between the populations based on the structure of the flavonoid aglycones and their glycosides. Differences in the aglycone composition were observed in populations from all the sites studied. In some cases the variation consisted in the type or in the amount of the different aglycones found; in other cases the differences were in the type and in the number of sugars obtained after hydrolysis of the glycosides, even when these results could not be used for diagnostic purposes.

Quantitative differences in the aglycone content were observed in populations from sites 1, 2, 4 and 5. In this sense, in populations 1 and 4 there is a predominance of kaempferol glycosides, site 2 showed similar quantities of kaempferol and quercetin plus isorhamnetin glycosides and site 5 is the only one in which quercetin is clearly abundant in leaf and flower extracts.

The most outstanding feature related to the aglycone content is the presence of methylated structures such as the 7-methyl ethers of kaempferol and quercetin in site 3 . These compounds were not identified in any other population and are therefore characteristic of this one. This reflects the expression of a characteristic or biochemical adaptation which requires the use of a more complex biosynthetic pathway that allows the modification of the basic structure of the flavonols.

The CCA analysis was used to identify the best linear combinations of the environmental variables that influence the flavonoids variables in plant tissues. The results obtained are in concordance with the phytochemical results. It is clear that the flavonoid profile of population from site 3 differed with the other populations sampled. The CCA study support this conclusion showing that quercetin 7-methyl ether and kaempferol 7-methyl ether present in leaves were particularly important in L. tenuis plants growing in soils of high pH, EC and ESP (Figure 2)

Taking into account our previous works ${ }^{21,22}$ and the results obtained herein, it could be deduced that the San Vicente (site 3) population represents an ecotype of very well defined soil chemical characteristics, plant morphological characters and distinguished by its efficiency to absorb phosphorus from the soil. Owing to their uniqueness it would be interesting to investigate the presence of the methylated flavonoids in roots or root exudates as they might be useful as markers to study interactions with mycorrhiza, specially considering that roots of $L$. tenuis growing in site 3 were heavily colonized by arbuscular mycorrhizas even when the site was flooded during 7 months. ${ }^{23}$ It has been reported that flavonoid extracts from roots and shoots of white clover possess flavonoid mixtures which varied with soil growing conditions and quercetin, acacetin and rhamnetin were accumulated in roots of arbuscular mycorrhizas inoculated plants, whereas such compounds were not detected in noninoculated plants. ${ }^{11}$ The synthesis of flavonoids appears to increase the presence of arbuscular mycorrhiza even before colonization. ${ }^{12}$ However, in the present work the roots of the L. tenuis plants collected from the sites were all heavily colonized by arbuscular mycorrhizas being colonized a 90-97\% of root length. Thus, the differences in flavonoids content cannot be explained by differences in magnitudes of mycorrhizal colonization between Lotus populations.

From an edaphic and climatic standpoint, the prevalence of stressful conditions such as salinity and sodicity of 
soil, together with periods of flooding, render site 3 a very different habitat from all other sites. This fact might imply that the quali and quantitative differences of flavonoid content exhibited by $L$. tenuis plants growing in these environmental conditions could be attributed to the existence of a different ecotype in this site. In the future, it would be interesting to analyse whether there is a connection between the phosphorus content of L. tenuis tissues and the type and amount of flavonoids detected in the plant, as a means to determine if ecotypes associated to different environments can be distinguished by their capacity to absorb and use the phosphorus which is available in the soil. ${ }^{6}$ In addition, this could provide an explanation of the successful spread and adaptation of L. tenuis in the Pampas, thus providing background information for future grassland management strategies.

\section{Supplementary Information}

Supplementary data are available free of charge at http://jbcs.sbq.org.br, as PDF file.

\section{Conclusions}

Only those samples of $L$. tenuis populations of the "Flooding Pampas"collected from a saline-sodic lowland and poor in terms of soil conditions for plant growth, showed the methylated aglycones: kaempferol 7-methyl ether and quercetin 7-methyl ether. The different flavonoid profile obtained from samples which grow in a variety of soils could constitute an additional tool for distinguishing ecotypes, coinciding with the differences in the observed morphological characteristics.

\section{References}

1. Blumenthal, M. J.; McGraw, R. L.; Trefoil: The Science and Technology of Lotus; American Society of Agronomy Inc.: Wisconsin, USA, 1999.

2. Mazzanti, A.; Montes, L.; Minon, D.; Sarlangue, H.; Chepi, C.; Rev. Argent. Prod. Anim. 1988, 8, 301.

3. Rosso, O. R.; Gómez, P. O.; Rev. Argent. Prod. Anim. 1995, 15, 364.
4. Cauhépe, M.; Lotus Newsletter 2004, 34, 30.

5. Stoffella, S. L.; Posse, G.; Collantes, M. B.; Ecologia Austral 1998, 8, 57.

6. Mendoza, R.; Pagani, E.; Pomar, M. C.; Ecologia Austral 2000, $10,3$.

7. Mendoza, R.; Pagani, E.; J. Plant Nutr. 1997, 20, 625.

8. Reynaud L.; Lussignol M.; Lotus Newsletter 2005, 35, 75.

9. Kade, M.; Wagner, M. L.; Strittmatter, C. D.; Ricco, R. A.; Gurni A. A.; Seed Sci. Technol. 1997, 25, 585.

10. Filip, R.; Ferraro, G.; Basualdo, N.; Mendoza, R. E.; García, I.; Abstract of the XXX Jornadas Argentinas de Botánica, Rosario, Santa Fe, Argentina, 2005.

11. Ponce, M. A.; Scervino, J. M.; Erra-Balsells, R.; Ocampo, J. A.; Godeas, A. M.; Phytochemistry 2004, 65, 1925.

12. Larose, G.; Chênevert, R.; Moutoglis, P.; Gagné, S.; Piché, Y.; Vierheilig, H.; J. Plant Physiol. 2002, 159, 1329.

13. Jackson, M. L.; Method of Soil Analysis Part 2. Chemical and Microbiological Properties; Prentice Hall, Inc.: Englewood Cliffs, 1958.

14. McGonigle, T. P.; Miller, M. H.; Evans, D. G.; Fairchaild, G. L.; Swan, J. A.; New Phytol. 1990, 115, 495.

15. Mabry, T. J.; Markham, K. R.; Thomas, M. B.; The Systematic Identification of Flavonoids, Springer: New York, 1970.

16. Wagner, H.; Bladt, S.; Plant Drug Analysis: A Thin Layer Chromatography Atlas, $2^{\text {nd. }}$ ed., Springer-Verlag: Berlin, 1996.

17. Harborne, J. B.; Phytochemical Methods: A Guide to Modern Techniques of Plant Analysis, $3^{\text {rd }}$ ed., Chapman \& Hall: London, 1998.

18. Horbowics, M.; Obendorf, R. L.; Seed Sci. Res. 1994, 4, 385.

19. Ter Braak, C. J. F.; CANOCO-a FORTRAN Program for Canonical Community Ordination. Microcomputer Power, Ithaca, New York, 1987-1992.

20. Richards, L. A.; Diagnóstico y Rehabilitación de Suelos Salinos y Sódicos; Laboratorio de Agricultura de los Estados Unidos, Limusa: México, 1974.

21. Kade, M.; Pagani, E.; Mendoza, R.; Commun. Soil Sci. Plant Anal. 2003, 34, 271.

22. Kade, M.; Pagani, E.; Mendoza, R.; Agronomie 2003, 23, 203.

23. Escudero, V.; Mendoza, R. E.; Mycorrhiza 2005, 15, 291.

Submitted: August 31, 2009

Published online: June 2, 2010 


\section{Flavonoids of Lotus tenuis (Waldst. \& Kit.) as Markers of Populations Growing in Soils of Different Saline and Hydrologic Conditions}

\section{Graciela Ferraro, Rosana Filip, ${ }^{*, a}$ María A. del Pero, ${ }^{a}$ Norma Basualdo, ${ }^{a}$ Rodolfo Mendoza $a^{b}$ and Ileana García ${ }^{b}$}

${ }^{a}$ Plant Physiology, School of Pharmacy and Biochemistry, IQUIMEFA (UBA-CONICET),

University of Buenos Aires, Junín 956, 1113 Buenos Aires, Argentina

${ }^{b}$ Bernardino Rivadavia, Argentine Museum of Natural Sciences (CONICET),

Av. Ángel Gallardo, 470, 1405 Buenos Aires, Argentina

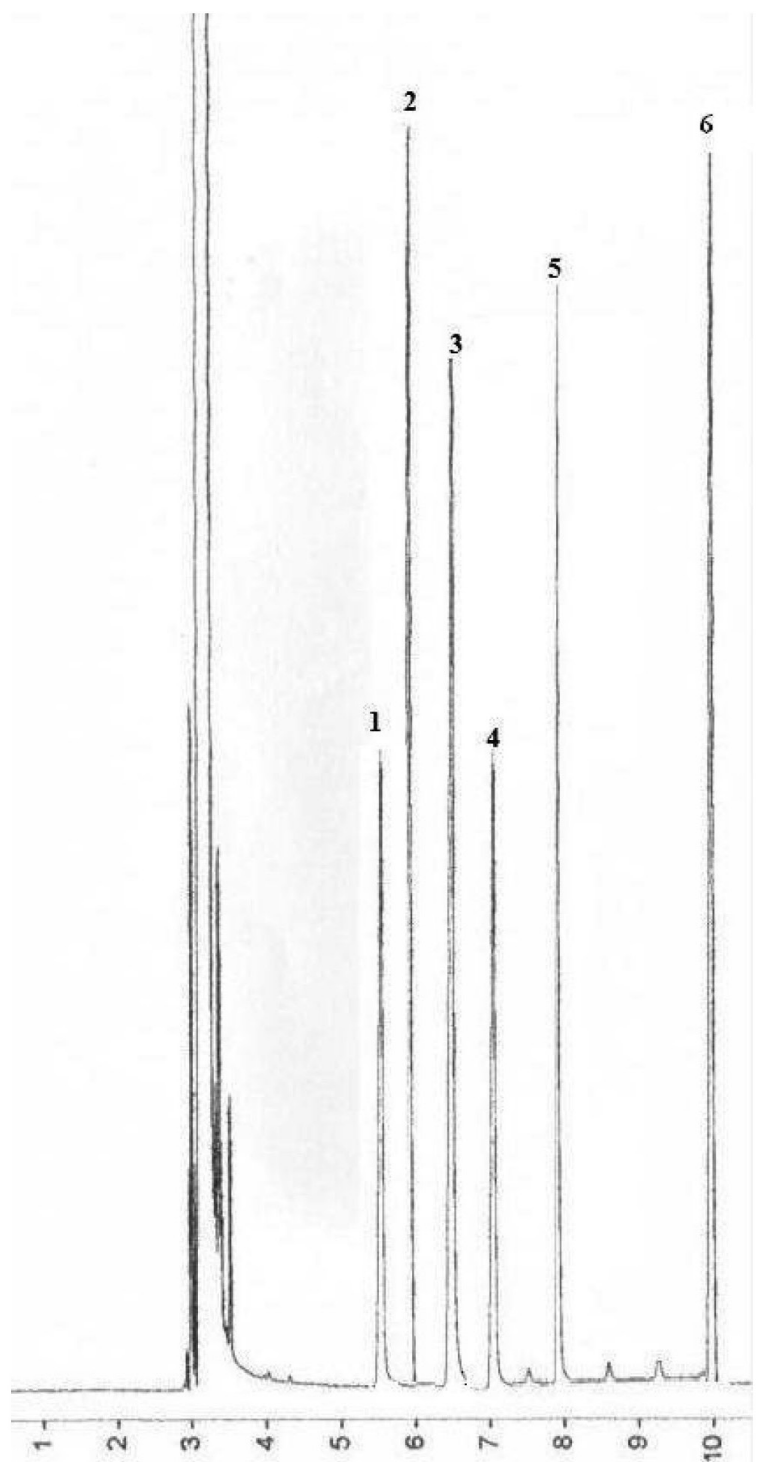

Figure 1. GC of TMSI-derivatized sugars. DB-5 capillary column $(60 \mathrm{~m} \times 0.25 \mathrm{~mm}, 0.25 \mu \mathrm{m})$. Compounds peck identification: 1 D-xylose, $2 \mathrm{~L}-\mathrm{rhamnose}$, 3 D-galactose, 4 D-glucose, 5 D-fructose, 6 D-glucuronic acid. 


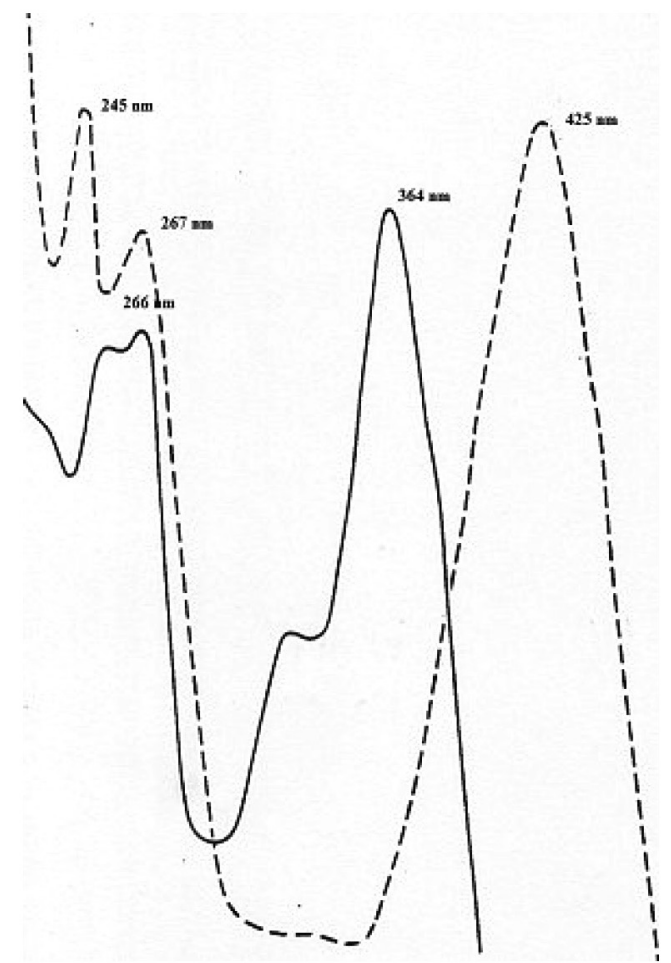

Figure 2. UV spectra of kaempferol 7-methyl ether. $\mathrm{MeOH}(-)$ and (- - ) $\mathrm{MeOH}+\mathrm{NaOMe}$.

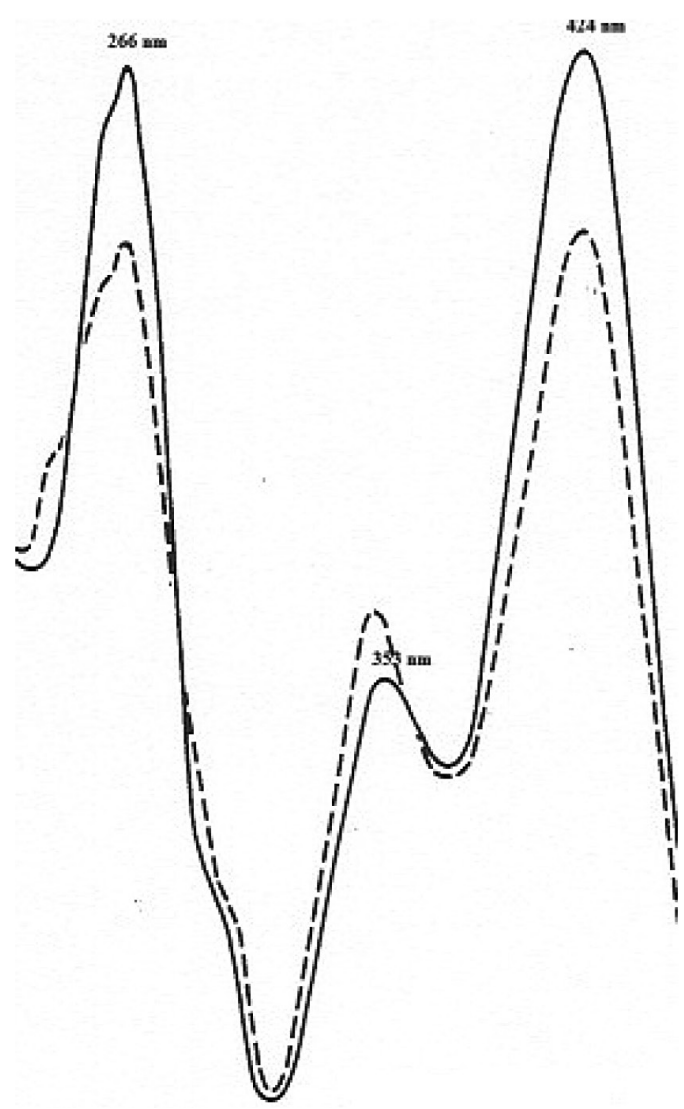

Figure 3. UV spectra of kaempferol 7-methyl ether. $\mathrm{MeOH}+\mathrm{AlCl}_{3}(-)$ and $\mathrm{MeOH}+\mathrm{AlCl}_{3}+\mathrm{HCl}(---)$.

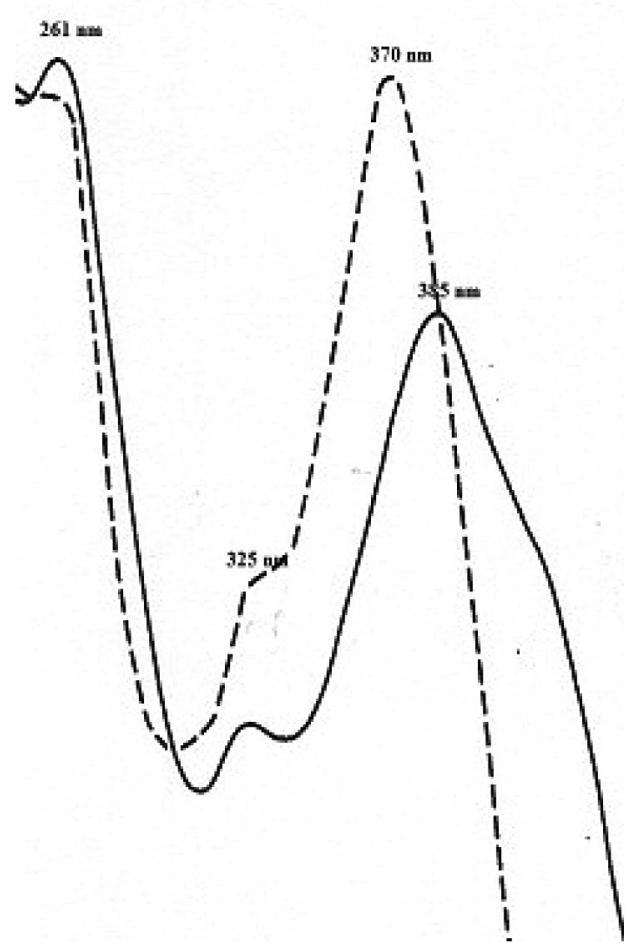

Figure 4. UV spectra of kaempferol 7-methyl ether. $\mathrm{MeOH}+\mathrm{NaOAc}(-)$ and $\mathrm{MeOH}+\mathrm{NaOAc}+\mathrm{H}_{3} \mathrm{BO}_{3}(---)$.

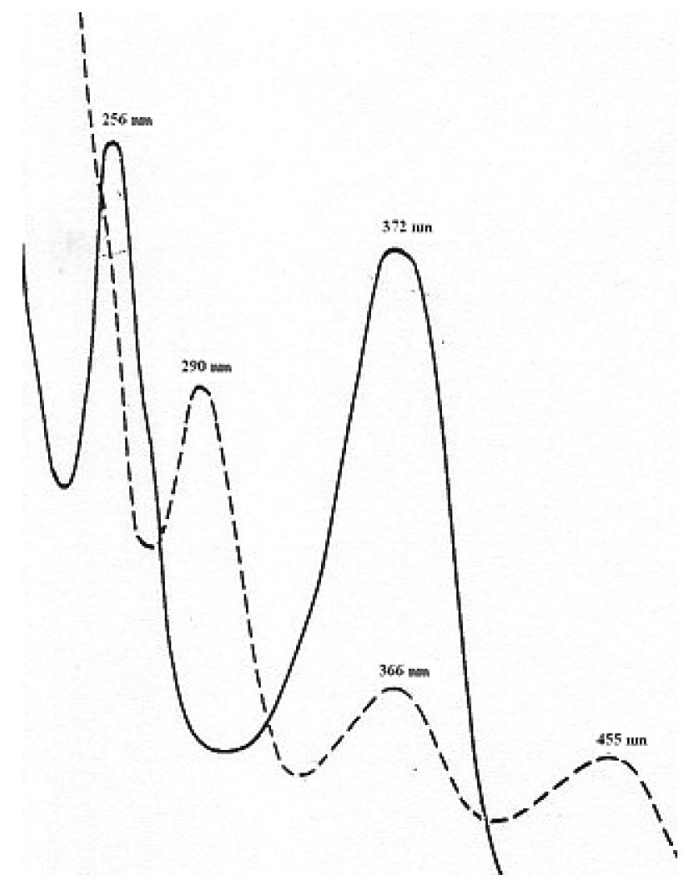

Figure 5. UV spectra of quercetin 7-methyl ether. $\mathrm{MeOH}(-)$ and $\mathrm{MeOH}+\mathrm{NaOMe}(---)$. 


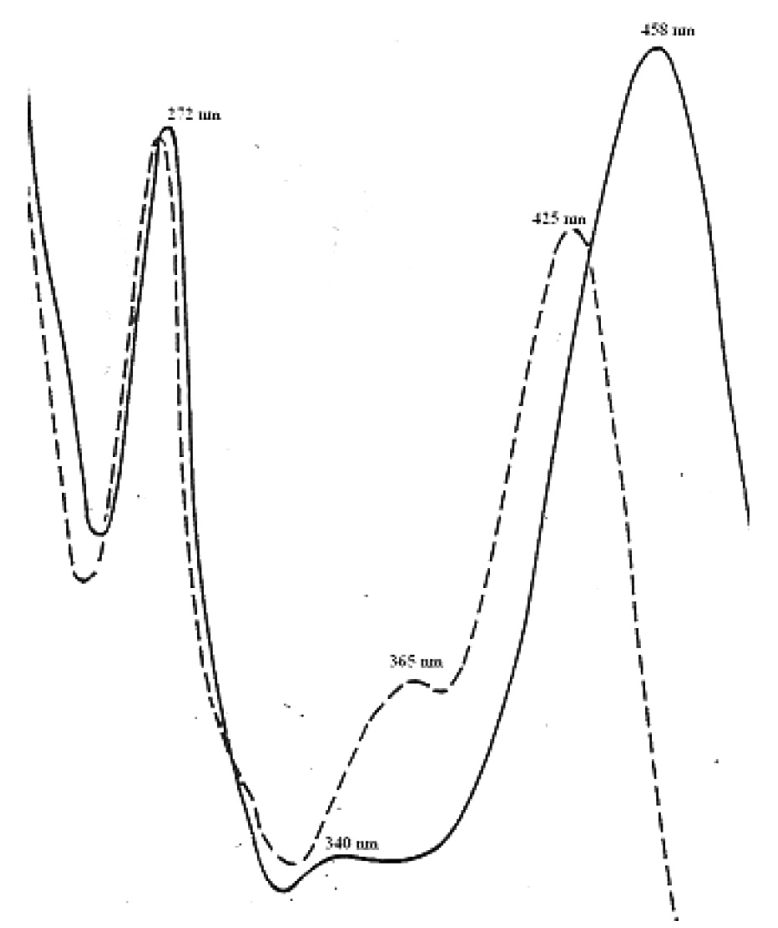

Figure 6. UV spectra of quercetin 7-methyl ether. $\mathrm{MeOH}+\mathrm{AlCl}_{3}(-)$ and $\mathrm{MeOH}+\mathrm{AlCl}_{3}+\mathrm{HCl}(---)$.

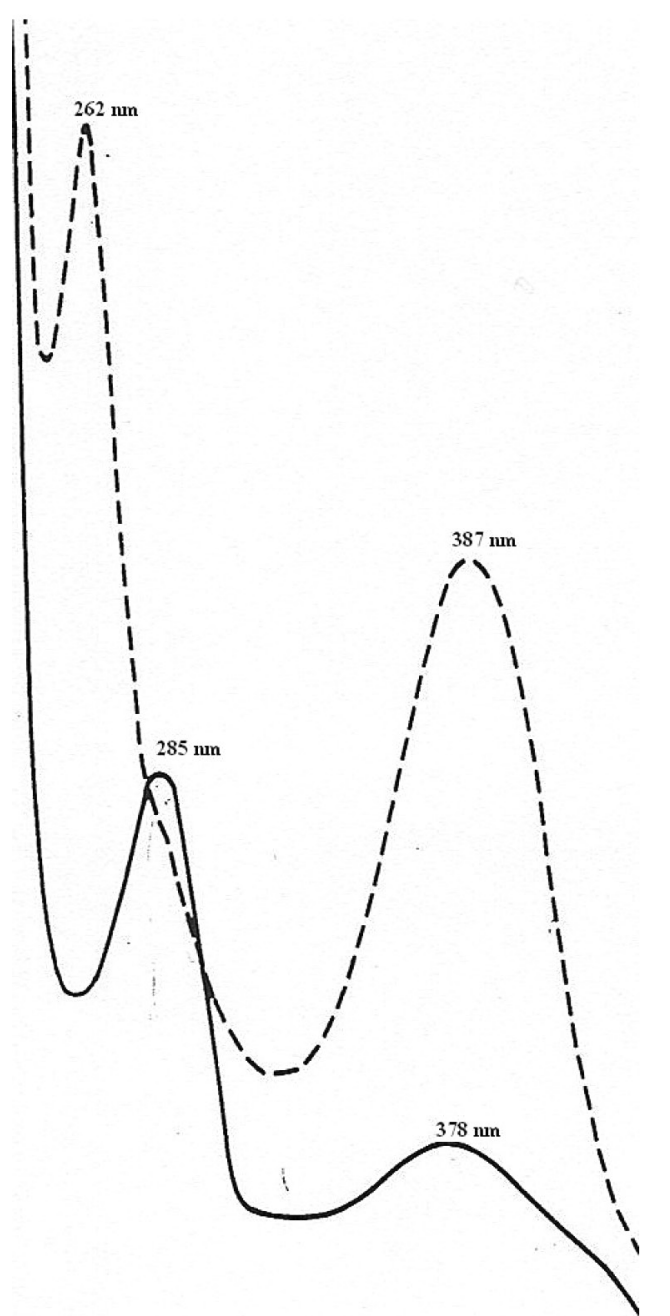

Figure 7. UV spectra of quercetin 7-methyl ether. $\mathrm{MeOH}+\mathrm{NaOAc}(-)$ and $\mathrm{MeOH}+\mathrm{NaOAc}+\mathrm{H}_{3} \mathrm{BO}_{3}(---)$. 